\title{
Sample Size for Morphological Traits of Sunn Hemp
}

\author{
Denison Esequiel Schabarum ${ }^{1}$, Alberto Cargnelutti Filho ${ }^{2}$, André Lavezo ${ }^{1}$, Diego Nicolau Follmann ${ }^{2}$, \\ Jéssica Andiara Kleinpaul ${ }^{1}$, Gabriela Görgen Chaves $^{1} \&$ Rafael Vieira Pezzini ${ }^{1}$ \\ ${ }^{1}$ Postgraduate Program in Agronomy, Federal University of Santa Maria, Santa Maria, Brazil \\ ${ }^{2}$ Department of Crop Science, Federal University of Santa Maria, Santa Maria, Brazil \\ Correspondence: Alberto Cargnelutti Filho, Avenida Roraima, n 1000, Bairro Camobi, CEP 97105-900, Santa \\ Maria, RS, Brazil. Tel: 55-55-3220-8899. E-mail: alberto.cargnelutti.filho@gmail.com
}

Received: September 19, 2017

Accepted: November 8, 2017

Online Published: December 15, 2017

doi:10.5539/jas.v10n1p152

URL: https://doi.org/10.5539/jas.v10n1p152

\begin{abstract}
Sunn hemp (Crotalaria juncea L.) is an annual leguminous plant used for crop rotation, biomass formation, biological nitrogen fixation, and nematode control. To this end, sampling is an important tool owing to its advantages, such as low cost and fast data acquisition. This study aimed to determine the sample size required to estimate the mean morphological traits of sunn hemp and to assess sample size variability among traits, crop development stages, and sowing seasons. Two uniformity trials were performed in the field during the 2014/2015 harvest. Crops were sown in October and December on an experimental area of the Department of Crop Science at the Federal University of Santa Maria, Brazil. An area of 1,200 $\mathrm{m}^{2}$ was allocated for each trial. Each trial was divided into $2 \mathrm{~m} \times 2 \mathrm{~m}$ grids, which formed 25 rows and 12 columns. One plant was marked per plot, totaling 300 plants in each trial. Leaf number and plant height were assessed weekly. Stem diameter and root length were measured at flowering. Normality and randomness tests were performed on each trait. The sample sizes (plants number) were calculated for the confidence interval half-widths (estimation errors) of the $2,4, \ldots, 20 \%$ mean estimates. There is variability of the sample size (plants number) between morphological traits, crop development stages, and sowing seasons. When choosing a single sample size to evaluate the morphological traits of sunn hemp, at least 70 plants should be sampled for an accuracy of $10 \%$ and a $95 \%$ confidence level.
\end{abstract}

Keywords: Crotalaria juncea L., experimental design, sample dimensioning

\section{Introduction}

Sunn hemp (Crotalaria juncea L.) is a summer forage crop used extensively in crop rotation. It is efficient as a soil cover and has high biomass production level. It is effective in biological nitrogen fixation and is outstanding as a source of green manure. It also helps control nematodes (Silva et al., 2014; Wang, Mcsorley, Marshall, \& Gallaher, 2004). It is seldom cultivated in southern Brazil. Nevertheless, as with the increase in nematode infestation and the delay in the development of resistant cultivars, the demand for a forage crop with qualities like sunn hemp is on the rise in this region.

Further studies that focusing on minimizing experimental errors are needed in order to enable technicians and farmers to safely and effectively use the new crop-related technologies. Sample sizes indicated for similar crops or determined as a function of the test area or the number of treatments are commonly used to determine the required experimental sample size. Statistically, this practice is unsuitable since sample size depends on experimental area heterogeneity and specific crop characteristics (Storck, Lopes, Cargnelutti Filho, Martini, \& Carvalho, 2007).

Sampling is a widely used method in population studies because it has many advantages including low cost and fast data acquisition. In most cases, the greater the sample size, the greater the accuracy. Therefore, the coefficient of variation decreases because a larger sample size reduces variance in the sample mean; nevertheless, costs and sampling time increase (Bussab \& Morettin, 2011). In contrast, small sample sizes may decrease experimental accuracy. Thus, using a sample size appropriate to the population characteristics is crucial when planning a research study.

Several studies have been conducted on the assessment of sample size in pigeon pea (Facco et al., 2015); white lupine (Burin, Cargnelutti Filho, Alves, \& Fick, 2014); turnip (Cargnelutti Filho et al., 2014); jack bean and velvet bean (Cargnelutti Filho et al., 2012); soybean (Cargnelutti Filho, Evangelista, Gonçalves, \& Storck, 2009); and 
common bean (Cargnelutti Filho, Ribeiro, Storck, Jost, \& Poersch, 2008). These studies estimate sample sizes adjusted to the characteristics of each crop. Only one report Teodoro et al. (2015) was found on an experiment estimating the sample size for the productive traits of sunn hemp. To our knowledge, no study has estimated the sample size for morphological traits of sunn hemp. Studies have been performed using sample sizes of one plant per experimental unit for leaf number and plant height (Lopes, Queiroz, \& Moreira, 2005), and three (Salviano, G. S. Souza, Araújo, Z. M. Souza, \& Vieira, 2013), five (Kappes, M. V. Arf, O. Arf, Gitti, \& Ferreira, 2012), ten (Dourado, Silva, \& Bolonhezi, 2001; Masson, Santana, Barbosa, Colman, \& Scalon, 2015), and 120 plants per plot for plantt height alone (Both et al., 2011).

Sample size is directly proportional to data heterogeneity and the degree of confidence desired in the estimate. The greater the degree of confidence, the lower the error values, which may be determined by the researcher in the experimental planning phase. Nevertheless, sample size may be estimated to obtain the desired accuracy (Cargnelutti Filho et al., 2009). The lower the estimation error allowed, the higher the number of observations to be evaluated. The estimation error may be preset by the researcher (Barbetta, Reis, \& Bornia, 2010; Bussab \& Morettin, 2011).

The present study, therefore, aimed to determine the sample size required to estimate the mean morphological traits of sunn hemp and to assess sample size variability among traits, crop development stages, and sowing seasons.

\section{Material and Methods}

Two uniformity trials (experiments without treatments) were performed on sunn hemp (Crotalaria juncea L.) in the experimental area of the Department of Plant Science at the Federal University of Santa Maria, Santa Maria City, Rio Grande do Sul State, latitude: $29^{\circ} 42^{\prime}$ S, longitude: $53^{\circ} 49^{\prime} \mathrm{W}$, and $95 \mathrm{~m}$ altitude. The climate of the region is Cfa - humid subtropical, without a defined dry season and with hot summers (Köppen climate classification). The soil type belongs to the São Pedro soil-mapping unit and is classified as a sandy dystrophic red Argisol according to the Brazilian soil classification system (Empresa Brasileira de Pesquisa Agropecuária [Embrapa], 1999).

In the uniformity trials (sowing, fertilization, treatments, and evaluations) were all performed in the same manner in all experimental area. Trials were performed during the 2014/2015 harvest in two sowing periods, on October 22, 2014 and on December 3, 2014. Sunn hemp was seeded in $0.5 \mathrm{~m}$ rows at a density of 20 seeds $\mathrm{m}^{-1}$ in a $50 \mathrm{~m} \times 52 \mathrm{~m}$ experimental area $\left(2,600 \mathrm{~m}^{2}\right)$.

After the experiment was set up, a $2 \mathrm{~m} \times 2 \mathrm{~m}$ grid was marked with piles in the central area $(24 \mathrm{~m} \times 50 \mathrm{~m}=1,200$ $\mathrm{m}^{2}$ ) in each trial, forming 25 rows and 12 columns. One plant closest to a pile dividing each grid was selected per unit; thus, a total of 300 plants were selected in each trail. Plant height and leaf number of the marked plants were measured weekly during the crop growth cycle. At flowering, stem diameter was measured using callipers $5 \mathrm{~cm}$ above the soil surface, and root length was obtained using a tape measure.

The first evaluation was performed 22 days after sowing (DAS). Subsequent measurements were performed at $27,33,40,48,53,60,68,76,83,90$, and 97 DAS. The final evaluation was performed at flowering, 110 DAS. The same methods were used in both sowing seasons and were scheduled at the same planting and growth dates. Thus, in the second season, the first evaluation was performed 18 DAS, then at 26, 34, 40, 47, 54, 62, 69, 78, and 83 DAS until flowering at 89 DAS. At flowering, the marked plants were harvested and the stem diameter $5 \mathrm{~cm}$ above the soil and the root length were measured.

After data collection, normality was assessed using the Kolmogorov-Smirnov test (Campos, 1983) and randomness was rated with the Wald-Wolfowitz runs test and the median and column direction values (Campos, 1983). The descriptive statistics calculated included the minimum, maximum, mean, median, standard deviation, standard error, coefficient of variation, and variance. Sample size $(\eta)$ was calculated for each trait using confidence interval half-widths (estimation errors) of $2,4, \ldots, 20 \%$ mean estimates $(\mathrm{m})$ with a $95 \%$ confidence coefficient $(1-\alpha)$ of the expression:

$$
\eta=\frac{\mathrm{t}_{\alpha / 2}^{2} \cdot \mathrm{s}^{2}}{\text { (Estimation error) }^{2}}
$$

The critical value of the Student's $t$ distribution is $t_{\alpha / 2}$. Its area to the right of the mean is $\alpha / 2$, its $t$ value is such that $P\left(t>t_{\alpha / 2}\right)=\alpha / 2$ with $(n-1)$ degrees of freedom; $\alpha=5 \%$ probability of error and $\mathrm{s}^{2}$ is the variance estimate (Barbetta et al., 2010; Bussab \& Morettin, 2011).

In the equation used to calculate sample size, $\eta$ was set to 300 plants. The estimation error was expressed as a percentage of the mean estimate $(\mathrm{m})$ and was calculated for each trait using the equation: 


$$
\text { Estimation error }=100 \times \frac{\mathrm{t}_{\alpha / 2} \cdot \mathrm{s}}{\sqrt{\eta} \cdot \mathrm{m}}
$$

Where, $\mathrm{s}$ is the standard deviation estimate. The calculations were performed with the help of Microsoft Office Excel $^{\circledR}$ application.

\section{Results and Discussion}

The leaf number between the first- and last evaluations ranged from 1-237 leaves for the first sowing season (sowing date October 22, 2014) and from 2-147 for the second sowing season (sowing date December 3, 2014) (Table 1). The lower mean leaf number of the second sowing most likely resulted from the fact that the flowering period of the second sowing season was 21 days shorter than that of the first sowing season. Similar results were reported by Timossi, Teixeira and Cava (2014), who found that late sunn hemp sowing shortened vegetative growth and the time to flowering. Santos and Júnior (2003) noted that late sowing decreased mean plant height. The yield reductions were attributed to the sensitivity of this crop to photoperiod (Alcântara, Furtini Neto, Paula, Mesquita, \& Muniz, 2000).

Table 1. Minimum (min), maximum (max), mean, median, standard deviation (SD), standard error (SE), coefficient of variation (CV), variance (VAR), value of Kolmogorov-Smirnov normality test (KS) and p-value of randomness the Run Test (Run), the leaf number in 300 plants sunn hemp (Crotalaria juncea L.), evaluated in two sowing seasons

\begin{tabular}{|c|c|c|c|c|c|c|c|c|c|c|}
\hline $\mathrm{DAS}^{(1)}$ & Min & Max & Mean & Median & SD & SE & $\mathrm{CV}(\%)$ & VAR & $\mathrm{KS}^{(2)}$ & $\operatorname{Run}^{(3)}$ \\
\hline \multicolumn{11}{|c|}{ First sowing season (October 22, 2014) } \\
\hline 22 & 1 & 11 & 5.35 & 5 & 1.85 & 0.11 & 34.54 & 3.42 & $2.35^{*}$ & 0.01 \\
\hline 27 & 3 & 16 & 8.16 & 8 & 2.21 & 0.13 & 27.05 & 4.87 & $2.16^{*}$ & 0.06 \\
\hline 33 & 8 & 30 & 14.90 & 14 & 3.92 & 0.23 & 26.33 & 15.40 & $1.63^{*}$ & 0.13 \\
\hline 40 & 11 & 49 & 25.54 & 25 & 6.71 & 0.39 & 26.26 & 44.97 & $1.40^{*}$ & 0.15 \\
\hline 48 & 16 & 74 & 38.81 & 38 & 9.63 & 0.56 & 24.81 & 92.74 & $1.12^{\mathrm{ns}}$ & 0.03 \\
\hline 53 & 21 & 80 & 47.19 & 46.5 & 11.29 & 0.65 & 23.93 & 127.48 & $0.99^{\mathrm{ns}}$ & 0.02 \\
\hline 60 & 26 & 92 & 58.96 & 59 & 13.05 & 0.75 & 22.14 & 170.37 & $0.66^{\mathrm{ns}}$ & 0.05 \\
\hline 68 & 36 & 120 & 75.47 & 76 & 15.01 & 0.87 & 19.89 & 225.42 & $0.87^{\text {ns }}$ & 0.84 \\
\hline 76 & 41 & 148 & 92.16 & 93.5 & 16.66 & 0.96 & 18.08 & 277.67 & $0.88^{\text {ns }}$ & 0.79 \\
\hline 83 & 45 & 173 & 108.66 & 109 & 19.06 & 1.10 & 17.54 & 363.38 & $1.14^{\mathrm{ns}}$ & 0.17 \\
\hline 90 & 60 & 185 & 121.65 & 123.5 & 19.07 & 1.10 & 15.67 & 363.49 & $1.05^{\mathrm{ns}}$ & 0.06 \\
\hline 97 & 64 & 192 & 132.74 & 134 & 19.92 & 1.15 & 15.01 & 396.91 & $1.02^{\mathrm{ns}}$ & 0.66 \\
\hline 110 & 67 & 237 & 146.43 & 146.5 & 22.06 & 1.27 & 15.07 & 486.71 & $0.75^{\mathrm{ns}}$ & 0.64 \\
\hline \multicolumn{11}{|c|}{ Second sowing season (December 3,2014 ) } \\
\hline 18 & 2 & 7 & 3.45 & 3 & 1.37 & 0.08 & 39.78 & 1.88 & $3.37^{*}$ & 0.00 \\
\hline 26 & 5 & 24 & 13.24 & 13 & 3.45 & 0.20 & 26.06 & 11.91 & $1.69^{*}$ & 0.00 \\
\hline 34 & 8 & 30 & 18.16 & 18 & 4.79 & 0.28 & 26.40 & 22.98 & $1.04^{\mathrm{ns}}$ & 0.01 \\
\hline 40 & 10 & 46 & 26.33 & 26 & 6.58 & 0.38 & 24.99 & 43.29 & $1.50^{*}$ & 0.00 \\
\hline 47 & 11 & 66 & 38.31 & 36 & 10.29 & 0.59 & 26.85 & 105.78 & $2.09^{*}$ & 0.00 \\
\hline 54 & 16 & 97 & 54.38 & 52 & 15.38 & 0.89 & 28.28 & 236.46 & $1.18^{\mathrm{ns}}$ & 0.01 \\
\hline 62 & 21 & 108 & 65.22 & 63 & 16.97 & 0.98 & 26.02 & 288.04 & $1.27^{\mathrm{ns}}$ & 0.02 \\
\hline 69 & 26 & 122 & 75.10 & 74 & 18.58 & 1.07 & 24.74 & 345.10 & $0.85^{\text {ns }}$ & 0.05 \\
\hline 78 & 28 & 128 & 80.38 & 79 & 19.26 & 1.11 & 23.96 & 370.81 & $1.07^{\mathrm{ns}}$ & 0.03 \\
\hline 83 & 32 & 138 & 87.13 & 86 & 20.53 & 1.19 & 23.56 & 421.46 & $0.79^{\mathrm{ns}}$ & 0.01 \\
\hline 89 & 43 & 147 & 94.37 & 93.5 & 21.23 & 1.23 & 22.49 & 450.53 & $0.79^{\text {ns }}$ & 0.00 \\
\hline
\end{tabular}

Note. ${ }^{(1)}$ Days after sowing. ${ }^{(2)} *$ Significant at $5 \%$ level of probability (not normally distributed). ${ }^{\text {ns }}$ Not significant (normally distributed). ${ }^{(3)}$ p-value $\leq 0.05$, significant at $5 \%$ probability (non-random data series).

Plant height showed a similar behavior to leaf number (Table 2). Between the first- and last evaluations, plant height ranged from $2.10-349.10 \mathrm{~cm}$ in the first sowing season and from $4-322.4 \mathrm{~cm}$ in the second sowing season. A shortened crop cycle may account for the fact that the mean plant height was lower in the second sowing 
season than the first.

Table 2. Minimum (min), maximum (max), mean, median, standard deviation (SD), standard error (SE), coefficient of variation (CV), variance (VAR), value of Kolmogorov-Smirnov normality test (KS) and p-value of randomness the Run Test (Run) the plant height in cm (weekly evaluations), stem diameter in $\mathrm{mm}$, and root length in $\mathrm{cm}$ (evaluation at harvest), in 300 plants sunn hemp (Crotalaria juncea L.), evaluated in two sowing seasons

\begin{tabular}{|c|c|c|c|c|c|c|c|c|c|c|}
\hline $\mathrm{DAS}^{(1)}$ & Min & Max & Mean & Median & SD & SE & CV (\%) & VAR & $\mathrm{KS}^{(2)}$ & $\operatorname{Run}^{(3)}$ \\
\hline \multicolumn{11}{|c|}{ First sowing season (October 22, 2014) } \\
\hline 22 & 2.10 & 19.00 & 8.33 & 8.20 & 2.77 & 0.16 & 33.19 & 7.65 & $1.10^{\mathrm{ns}}$ & 0.00 \\
\hline 27 & 3.10 & 26.40 & 12.81 & 12.30 & 3.80 & 0.22 & 29.66 & 14.43 & $1.09^{\mathrm{ns}}$ & 0.03 \\
\hline 33 & 5.40 & 47.70 & 20.10 & 19.50 & 6.33 & 0.37 & 31.47 & 40.01 & $1.32^{\mathrm{ns}}$ & 0.00 \\
\hline 40 & 9.10 & 82.00 & 39.84 & 38.40 & 13.34 & 0.77 & 33.47 & 177.83 & $1.03^{\mathrm{ns}}$ & 0.00 \\
\hline 48 & 18.10 & 133.90 & 75.93 & 77.50 & 20.09 & 1.16 & 26.46 & 403.54 & $0.60^{\text {ns }}$ & 0.00 \\
\hline 53 & 32.40 & 153.40 & 97.60 & 98.70 & 23.27 & 1.34 & 23.84 & 541.34 & $0.67^{\mathrm{ns}}$ & 0.00 \\
\hline 60 & 46.20 & 189.50 & 127.28 & 128.65 & 24.99 & 1.44 & 19.63 & 624.35 & $1.30^{\mathrm{ns}}$ & 0.00 \\
\hline 68 & 68.30 & 213.70 & 157.53 & 159.30 & 25.50 & 1.47 & 16.19 & 650.27 & $0.87^{\mathrm{ns}}$ & 0.03 \\
\hline 76 & 73.00 & 256.10 & 174.41 & 175.25 & 25.50 & 1.47 & 14.62 & 650.50 & $0.75^{\mathrm{ns}}$ & 0.14 \\
\hline 83 & 84.20 & 276.30 & 203.58 & 204.45 & 26.96 & 1.56 & 13.24 & 726.85 & $0.75^{\mathrm{ns}}$ & 0.50 \\
\hline 90 & 118.80 & 295.80 & 234.76 & 237.80 & 27.87 & 1.61 & 11.87 & 776.99 & $1.06^{\mathrm{ns}}$ & 0.34 \\
\hline 97 & 130.60 & 315.00 & 260.71 & 263.70 & 27.56 & 1.59 & 10.57 & 759.62 & $1.65^{*}$ & 0.24 \\
\hline 110 & 138.30 & 349.10 & 288.73 & 290.55 & 30.44 & 1.76 & 10.54 & 926.68 & $1.95^{*}$ & 0.43 \\
\hline $\mathrm{SD}^{(4)}$ & 3.50 & 23.93 & 15.24 & 15.40 & 4.11 & 0.24 & 26.94 & 16.86 & $0.85^{\mathrm{ns}}$ & 0.00 \\
\hline $\mathrm{RL}^{(5)}$ & 6.50 & 32.30 & 16.27 & 15.80 & 5.01 & 0.29 & 30.82 & 25.15 & $1.06^{\mathrm{ns}}$ & 0.00 \\
\hline \multicolumn{11}{|c|}{ Second sowing season (December 3, 2014) } \\
\hline 18 & 4 & 19 & 9.06 & 8.8 & 2.39 & 0.14 & 26.40 & 5.73 & $1.40^{*}$ & 0.00 \\
\hline 26 & 12.7 & 52 & 28.08 & 26.8 & 8.38 & 0.48 & 29.83 & 70.19 & $1.30^{\mathrm{ns}}$ & 0.00 \\
\hline 34 & 15.4 & 66.9 & 37.74 & 37.2 & 11.78 & 0.68 & 31.21 & 138.72 & $1.05^{\mathrm{ns}}$ & 0.00 \\
\hline 40 & 19.4 & 114.3 & 58.02 & 57.7 & 17.88 & 1.03 & 30.81 & 319.56 & $0.54^{\mathrm{ns}}$ & 0.00 \\
\hline 47 & 27.6 & 143.5 & 81.71 & 82.45 & 21.60 & 1.25 & 26.43 & 466.37 & $0.53^{\mathrm{ns}}$ & 0.00 \\
\hline 54 & 46.5 & 183.2 & 113.50 & 114.85 & 25.36 & 1.46 & 22.34 & 643.09 & $0.54^{\mathrm{ns}}$ & 0.00 \\
\hline 62 & 69.4 & 229.4 & 147.12 & 148.4 & 29.19 & 1.69 & 19.84 & 851.80 & $0.56^{\mathrm{ns}}$ & 0.00 \\
\hline 69 & 71.4 & 269.4 & 174.66 & 174.95 & 33.94 & 1.96 & 19.43 & 1151.85 & $0.68^{\mathrm{ns}}$ & 0.00 \\
\hline 78 & 87.6 & 272.6 & 192.24 & 192.25 & 34.86 & 2.01 & 18.13 & 1215.03 & $0.95^{\mathrm{ns}}$ & 0.00 \\
\hline 83 & 98.4 & 303 & 215.64 & 216.15 & 40.75 & 2.35 & 18.90 & 1660.81 & $0.71^{\mathrm{ns}}$ & 0.00 \\
\hline 89 & 106.8 & 322.4 & 232.68 & 231.75 & 42.82 & 2.47 & 18.40 & 1833.52 & $0.89^{\mathrm{ns}}$ & 0.00 \\
\hline $\mathrm{SD}^{(4)}$ & 2.52 & 21 & 9.89 & 9.705 & 3.38 & 0.20 & 34.20 & 11.45 & $1.25^{\mathrm{ns}}$ & 0.17 \\
\hline $\mathrm{RL}^{(5)}$ & 2.18 & 30.99 & 13.11 & 12.45 & 5.57 & 0.32 & 42.50 & 31.07 & $1.43^{*}$ & 0.04 \\
\hline
\end{tabular}

Note. ${ }^{(1)}$ Days after sowing. ${ }^{(2)} *$ Significant at $5 \%$ level of probability (not normally distributed). ${ }^{\text {ns }}$ Not significant (normally distributed). ${ }^{(3)}$ p-value $\leq 0.05$, significant at $5 \%$ probability (non-random data series). ${ }^{(4)} \mathrm{SD}$ : stem diameter (mm). ${ }^{(5)} \mathrm{RL}$ : root length $(\mathrm{cm})$.

Stem diameter ranged from 3.50-23.93 $\mathrm{mm}$ in the first sowing season and from 2.52-21 $\mathrm{mm}$ in the second (Table 2). Root length ranged from $6.50-32.30 \mathrm{~cm}$ in the first sowing season and from $2.18-30.99 \mathrm{~cm}$ in the second. The means of the stem diameter were $15.24 \mathrm{~mm}$ and $9.89 \mathrm{~mm}$, and those of the root length were $16.26 \mathrm{~cm}$ and 13.11 $\mathrm{cm}$ in the first- and second sowing seasons, respectively (Table 2). Differences in sample sizes may account for the variability in the stem diameter and root length between sowing seasons.

At harvest in the first- and second sowing seasons, respectively, the means were as follows: leaf number, 146 and 94; plant height, 288.73 and $232.68 \mathrm{~cm}$; stem diameter, 15.24 and $9.89 \mathrm{~mm}$; and root length, 16.27 and $13.11 \mathrm{~cm}$ (Tables 1 and 2). These data indicate good plant growth and corroborate the findings reported by Lopes et al. (2005), and Kappes et al. (2012), Salviano et al. (2013), who recorded means of $165 \mathrm{~cm}, 253 \mathrm{~cm}$, and $232 \mathrm{~cm}$ for plant height, respectively. Good plant growth lends credibility to the data and favors their use in future 
experiments.

Out of twenty-four evaluations, eight were not normally distributed for leaf number (Table 1) and two were not normally distributed for plant height (Table 2) according to the Kolmogorov-Smirnov test. Nevertheless, the distribution may be considered close to normality due to the high plants number (300) (Bussab \& Morettin, 2011). The analysis showed that the data for stem diameter in the first- and second sowing seasons and for root length in the first sowing season were normally distributed. The According to the Student's $t$-test, the morphology data obtained from this study were normally distributed and provided reliability to it. The runs test values (Campos, 1983) were calculated using the medians of the sunn hemp trait data and showed they were generally random. Nevertheless, in most cases, the assumption of randomness failed for the evaluations performed in the second sowing season. This error often occurs when the sample size is large, the traits are morphological, and the cultivar is genetically uniform.

In the first sowing season, the coefficient of variation $(\mathrm{CV})$ for the leaf number ranged from $15.07 \%$ at the end to $34.53 \%$ at the beginning of the crop cycle (Table 1). In the second sowing season, the CV ranged from $22.49 \%$ at the end to $39.78 \%$ at the beginning of the growth cycle. A similar behavior was observed for plant height (Table 2). It ranged from $10.54 \%$ at the end to $33.19 \%$ at the beginning in the first season, and from 18.40 at the end to $26.40 \%$ at the beginning in the second season, respectively. These values resemble those found by Facco et al. (2015) for node number per plant when assessing plant height in Crambe spp. (Cargnelutti Filho, Lopes, Toebe, Silveira, \& Schwantes, 2011). These results show that a larger sample size (plants number) is needed to estimate the mean leaf number and plant height at the beginning of the crop cycle in both sowing seasons.

The sample size (plants number) for confidence interval half-widths (estimation errors) of the 4\% mean estimate (m) and the 95\% confidence coefficient ranged from 55-289 plants in the first sowing season. In the second season, the sample size ranged from 123-384 plants at the same precision level (Table 3). These data indicate a higher variability at the beginning of the crop cycle in both seasons since a larger sample size is necessary then. Therefore, a well-planned sample size determination may reduce experimental errors (Storck, Garcia, Lopes, \& Estefanel, 2011). In a series of five experiments, Cargnelutti Filho et al. (2009) estimated the sample size (plants number) of 28 soybean genotypes for confidence interval half-widths (estimation errors) of 5\% mean estimate and $95 \%$ confidence coefficient for the nodes number per plant. They concluded that the plants number ranged from 32-115; Teodoro et al. (2014) determined that 259 and 362 plants respectively, were required to estimate the biomass and mean productivity of Canavalia ensiformis and Dolichos lablab at a 95\% confidence interval; Silva, Santos, Oliveira, Sousa and Fernandes (2015) found that ten plants were sufficient to estimate the leaf number, chapter diameter, stem diameter, and plant height in sunflower; Bandeira et al. (2016) reported that twelve fruits are sufficient to estimate mean luminosity, skin tone, and pulp tone of passion fruit with an estimation error of 5\% of the mean; Cargnelutti Filho et al. (2016) indicated that 16 and 59 hybrid eucalyptus trees are adequate to estimate the breast-height trunk diameter at three and seven years, respectively, and 31 plants are needed to estimate tree height. These studies show the importance of determining sample size for different crops and indicate the relevancy of future research on sunn hemp. 
Table 3. Sample size (plants number) to estimate the average the leaf number, for estimation errors equal to 2 , 4 , $6, \ldots, 20 \%$ of the mean estimate, and confidence interval half-widths (Error \%), based on 300 plants of sunn hemp (Crotalaria juncea L.), evaluated in two sowing seasons

\begin{tabular}{|c|c|c|c|c|c|c|c|c|c|c|c|}
\hline $\mathrm{DAS}^{(1)}$ & $2 \%$ & $4 \%$ & $6 \%$ & $8 \%$ & $10 \%$ & $12 \%$ & $14 \%$ & $16 \%$ & $18 \%$ & $20 \%$ & Error \% \\
\hline \multicolumn{12}{|c|}{ First sowing season (October 22, 2014) } \\
\hline 22 & 1156 & 289 & 129 & 73 & 47 & 33 & 24 & 19 & 15 & 12 & 3.92 \\
\hline 27 & 709 & 178 & 79 & 45 & 29 & 20 & 15 & 12 & 9 & 8 & 3.07 \\
\hline 33 & 672 & 168 & 75 & 42 & 27 & 19 & 14 & 11 & 9 & 7 & 2.99 \\
\hline 40 & 668 & 167 & 75 & 42 & 27 & 19 & 14 & 11 & 9 & 7 & 2.98 \\
\hline 48 & 597 & 150 & 67 & 38 & 24 & 17 & 13 & 10 & 8 & 6 & 2.82 \\
\hline 53 & 555 & 139 & 62 & 35 & 23 & 16 & 12 & 9 & 7 & 6 & 2.72 \\
\hline 60 & 475 & 119 & 53 & 30 & 19 & 14 & 10 & 8 & 6 & 5 & 2.52 \\
\hline 68 & 384 & 96 & 43 & 24 & 16 & 11 & 8 & 6 & 5 & 4 & 2.26 \\
\hline 76 & 317 & 80 & 36 & 20 & 13 & 9 & 7 & 5 & 4 & 4 & 2.05 \\
\hline 83 & 298 & 75 & 34 & 19 & 12 & 9 & 7 & 5 & 4 & 3 & 1.99 \\
\hline 90 & 238 & 60 & 27 & 15 & 10 & 7 & 5 & 4 & 3 & 3 & 1.78 \\
\hline 97 & 219 & 55 & 25 & 14 & 9 & 7 & 5 & 4 & 3 & 3 & 1.71 \\
\hline 110 & 220 & 55 & 25 & 14 & 9 & 7 & 5 & 4 & 3 & 3 & 1.71 \\
\hline \multicolumn{12}{|c|}{ Second sowing season (December 3, 2014) } \\
\hline 18 & 1533 & 384 & 171 & 96 & 62 & 43 & 32 & 24 & 19 & 16 & 4.52 \\
\hline 26 & 658 & 165 & 74 & 42 & 27 & 19 & 14 & 11 & 9 & 7 & 2.96 \\
\hline 34 & 675 & 169 & 75 & 43 & 27 & 19 & 14 & 11 & 9 & 7 & 3.00 \\
\hline 40 & 605 & 152 & 68 & 38 & 25 & 17 & 13 & 10 & 8 & 7 & 2.84 \\
\hline 47 & 698 & 175 & 78 & 44 & 28 & 20 & 15 & 11 & 9 & 7 & 3.05 \\
\hline 54 & 775 & 194 & 87 & 49 & 31 & 22 & 16 & 13 & 10 & 8 & 3.21 \\
\hline 62 & 656 & 164 & 73 & 41 & 27 & 19 & 14 & 11 & 9 & 7 & 2.96 \\
\hline 69 & 593 & 149 & 66 & 38 & 24 & 17 & 13 & 10 & 8 & 6 & 2.81 \\
\hline 78 & 556 & 139 & 62 & 35 & 23 & 16 & 12 & 9 & 7 & 6 & 2.72 \\
\hline 83 & 538 & 135 & 60 & 34 & 22 & 15 & 11 & 9 & 7 & 6 & 2.68 \\
\hline 89 & 490 & 123 & 55 & 31 & 20 & 14 & 10 & 8 & 7 & 5 & 2.56 \\
\hline
\end{tabular}

Note. ${ }^{(1)}$ Days after sowing.

The plant height data were obtained using a sample size range of 27-272 and 82-236 at the beginning of the crop cycle in the first- and second sowing seasons, respectively. Confidence interval half-widths (estimation errors) of the $4 \%$ mean estimate $(\mathrm{m})$ and $95 \%$ confidence coefficient were used (Table 4$)$. The sample size ranged from 176-284 for stem diameter and from 230-438 for root length in the first and second sowing seasons, respectively. The confidence interval half-widths (estimation errors) of $4 \%$ mean estimate $(\mathrm{m})$ and $95 \%$ confidence coefficient were applied to both traits. 
Table 4. Sample size (plants number) to estimate the average the plant height (weekly evaluations), stem diameter, and root length (evaluation at harvest), for estimation errors equal to $2,4,6, \ldots, 20 \%$ of the mean estimate, and confidence interval half-widths (Error \%), based on 300 plants of sunn hemp (Crotalaria juncea L.), evaluated in two sowing seasons

\begin{tabular}{|c|c|c|c|c|c|c|c|c|c|c|c|}
\hline $\mathrm{DAS}^{(1)}$ & $2 \%$ & $4 \%$ & $6 \%$ & $8 \%$ & $10 \%$ & $12 \%$ & $14 \%$ & $16 \%$ & $18 \%$ & $20 \%$ & Error \% \\
\hline \multicolumn{12}{|c|}{ First sowing season (October 22, 2014) } \\
\hline 22 & 1067 & 267 & 119 & 67 & 43 & 30 & 22 & 17 & 14 & 11 & 3.77 \\
\hline 27 & 852 & 213 & 95 & 54 & 35 & 24 & 18 & 14 & 11 & 9 & 3.37 \\
\hline 33 & 959 & 240 & 107 & 60 & 39 & 27 & 20 & 15 & 12 & 10 & 3.58 \\
\hline 40 & 1085 & 272 & 121 & 68 & 44 & 31 & 23 & 17 & 14 & 11 & 3.80 \\
\hline 48 & 678 & 170 & 76 & 43 & 28 & 19 & 14 & 11 & 9 & 7 & 3.01 \\
\hline 53 & 551 & 138 & 62 & 35 & 23 & 16 & 12 & 9 & 7 & 6 & 2.71 \\
\hline 60 & 374 & 94 & 42 & 24 & 15 & 11 & 8 & 6 & 5 & 4 & 2.23 \\
\hline 68 & 254 & 64 & 29 & 16 & 11 & 8 & 6 & 4 & 4 & 3 & 1.84 \\
\hline 76 & 208 & 52 & 24 & 13 & 9 & 6 & 5 & 4 & 3 & 3 & 1.66 \\
\hline 83 & 170 & 43 & 19 & 11 & 7 & 5 & 4 & 3 & 3 & 2 & 1.50 \\
\hline 90 & 137 & 35 & 16 & 9 & 6 & 4 & 3 & 3 & 2 & 2 & 1.35 \\
\hline 97 & 109 & 28 & 13 & 7 & 5 & 4 & 3 & 2 & 2 & 2 & 1.20 \\
\hline 110 & 108 & 27 & 12 & 7 & 5 & 3 & 3 & 2 & 2 & 2 & 1.20 \\
\hline $\mathrm{SD}^{(2)}$ & 703 & 176 & 79 & 44 & 29 & 20 & 15 & 11 & 9 & 8 & 3.06 \\
\hline $\mathrm{RL}^{(3)}$ & 920 & 230 & 103 & 58 & 37 & 26 & 19 & 15 & 12 & 10 & 3.50 \\
\hline \multicolumn{12}{|c|}{ Second sowing season (December 3, 2014) } \\
\hline 18 & 675 & 169 & 75 & 43 & 27 & 19 & 14 & 11 & 9 & 7 & 3.00 \\
\hline 26 & 862 & 216 & 96 & 54 & 35 & 24 & 18 & 14 & 11 & 9 & 3.39 \\
\hline 34 & 943 & 236 & 105 & 59 & 38 & 27 & 20 & 15 & 12 & 10 & 3.55 \\
\hline 40 & 920 & 230 & 103 & 58 & 37 & 26 & 19 & 15 & 12 & 10 & 3.50 \\
\hline 47 & 677 & 170 & 76 & 43 & 28 & 19 & 14 & 11 & 9 & 7 & 3.00 \\
\hline 54 & 484 & 121 & 54 & 31 & 20 & 14 & 10 & 8 & 6 & 5 & 2.54 \\
\hline 62 & 382 & 96 & 43 & 24 & 16 & 11 & 8 & 6 & 5 & 4 & 2.25 \\
\hline 69 & 366 & 92 & 41 & 23 & 15 & 11 & 8 & 6 & 5 & 4 & 2.21 \\
\hline 78 & 319 & 80 & 36 & 20 & 13 & 9 & 7 & 5 & 4 & 4 & 2.06 \\
\hline 83 & 346 & 87 & 39 & 22 & 14 & 10 & 8 & 6 & 5 & 4 & 2.15 \\
\hline 89 & 328 & 82 & 37 & 21 & 14 & 10 & 7 & 6 & 5 & 4 & 2.09 \\
\hline $\mathrm{SD}^{(2)}$ & 1133 & 284 & 126 & 71 & 46 & 32 & 24 & 18 & 14 & 12 & 3.89 \\
\hline $\mathrm{RL}^{(3)}$ & 1750 & 438 & 195 & 110 & 70 & 49 & 36 & 28 & 22 & 18 & 4.83 \\
\hline
\end{tabular}

Note. ${ }^{(1)}$ Days after sowing. ${ }^{(2)}$ SD: Stem diameter (mm). ${ }^{(3)}$ RL: Root length $(\mathrm{cm})$.

If a sample size of 300 plants is selected, then the error for the mean estimate (m) will range from $1.71-4.52 \%$ for the leaf number, $1.20-3.80 \%$ for the plant height, 3.06-3.89\% for the stem diameter, and $3.50-4.83 \%$ for the root length (Tables 3 and 4). Facco et al. (2015) reported similar values for pigeon pea.

The results indicate variability between growth phases for both leaf number and plant height. A higher sample size is necessary at the beginning of the crop cycle since there is greater variability in the observations. P. S. L. Silva, Barbosa, Goncalves, P. I. B. Silva, and Nunes (2005) noted this trend in corn. Sample size variation for the traits of white lupine was reported by Burin et al. (2014) and for the traits of peach and apple by Toebe, Both, Cargnelutti Filho, Brackmann, and Storck (2011). Variation between morphological traits is common because each is expressed differently depending on environmental stimuli. Nduhiu, Onyango, Makokha, and Mugai (2015) found significant effects of phosphate fertilization levels on different morphological traits of sunn hemp. Variability in sample size between sowing seasons was also found for pigeon pea (Facco et al., 2015).

The sampling accuracy of morphological traits with a $4 \%$ confidence interval is very high. Therefore, the plants 
number required to estimate the traits at this level of accuracy is also very high and often unfeasible. Traits may be estimated to a lower accuracy without compromising evaluation quality. The sample size for leaf number with a confidence interval half-width of 10\% ranged from 9-47 in the first sowing season and 20-62 in the second (Table 3). The sample size for plant height ranged from 5-44 in the first sowing season and 14-38 in the second, at the same confidence interval half-width. The sample size ranged from $29-46$ for stem diameter and from 37-70 for root length between the first and second sowing seasons, respectively. A $10 \%$ confidence interval half-width was used (Table 4). All sample sizes were estimated at a 95\% confidence interval.

\section{Conclusion}

The sample size (plants number) for sunn hemp differs among morphological traits. Sample sizes required to determine plant traits accurately are in the following order: Leaf number, plant height, stem diameter and root length. There is variability of the sample size (plants number) between the crop development stages, requiring a larger sample size at the beginning of crop development. There is variability in sample size (plants number) between sowing seasons. When choosing a single sample size to evaluate the morphological traits of sunn hemp, at least 70 plants should be sampled for an accuracy of $10 \%$ and a $95 \%$ confidence level.

\section{References}

Alcântara, F. A., Furtini Neto, A. E., Paula, M. B. de, Mesquita, H. A. de, \& Muniz, J. A. (2000). Adubação verde na recuperação da fertilidade de um Latossolo Vermelho-Escuro degradado. Pesquisa Agropecuária Brasileira, 35(2), 277-288. https://doi.org/10.1590/S0100-204X2000000200006

Bandeira, C. T., Fortes, S. K. G., Toebe, M., Saifert, L., Giacobbo, C. L., \& Welter, L. J. (2016). Sample size for estimate the average of Passiflora caerulea fruits traits. Ciência Rural, 46(10), 1729-1736. https://doi.org/ $10.1590 / 0103-8478 \mathrm{cr} 20150847$

Barbetta, P. A., Reis, M. M., \& Bornia, A. C. (2010). Estatística para cursos de engenharia e informática. São Paulo: Atlas.

Both, O. W., Abreu, F. F. M., Carvalho, T. G., Tziboy, E. A. T., Lamônica, G. A., \& Silva, A. A. F. (2011). Análise de crescimento e cobertura foliar de espécies utilizadas na adubação verde: Mucuna preta, mucuna cinza, crotalária e feijão-de-porco, no município de St. Antônio do Leverger. MT $63^{\mathrm{a}}$ Reunião Anual da SBPA: Sociedade Brasileira para o Progresso da Ciência.

Burin, C., Cargnelutti Filho, A., Alves, B. M., \& Fick, A. L. (2014). Dimensionamento amostral para a estimação da média e da mediana de caracteres de tremoço branco (Lupinus albus L.). Comunicata Scientiae, 5(2), 205-212.

Bussab, W. O., \& Morettin, P. A. (2011). Estatística básica. São Paulo: Saraiva.

Campos, H. (1983). Estatística experimental não-paramétrica. Piracicaba: Escola Superior de Agricultura "Luiz de Queiroz" da Universidade de São Paulo.

Cargnelutti Filho, A., Beltrame, R., Bisognin, D. A., Lazarotto, M., Haselein, C. R., Gatto, D. A., \& Santos, G. A. (2016). Sample size estimating average trunk diameter and plant height in eucalyptus hybrids. Ciência Rural, 46(7), 1192-1199. https://doi.org/10.1590/0103-8478cr20140836

Cargnelutti Filho, A., Evangelista, D. H. R., Gonçalves, E. C. P., \& Storck, L. (2009). Tamanho de amostra de caracteres de genótipos de soja. Ciência Rural, 39(4), 983-991. https://doi.org/10.1590/S0103-84782009 005000016

Cargnelutti Filho, A., Facco, G., Lúcio, A. D., Toebe, M., Burin, C., Fick, A. L., \& Neu, I. M. M. (2014). Tamanho de amostra para a estimação da média de caracteres morfológicos e produtivos de nabo forrageiro. Ciência Rural, 44(2), 223-227. https://doi.org/10.1590/S0103-84782014000200005

Cargnelutti Filho, A., Lopes, S. J., Toebe, M., Silveira, T. R., \& Schwantes, I. A. (2011). Tamanho de amostra para estimação do coeficiente de correlação de Pearson entre caracteres de Crambe abyssinica. Revista Ciência Agronômica, 42(1), 149-158. https://doi.org/10.1590/S1806-66902011000100019

Cargnelutti Filho, A., Ribeiro, N. D., Storck, L., Jost, E., \& Poersch, N. L. (2008). Tamanho de amostra de caracteres de cultivares de feijão. Ciência Rural, 38(3), 635-642. https://doi.org/10.1590/S0103-84782008 000300007

Cargnelutti Filho, A., Toebe, M., Burin, C., Fick, A. L., Alves, B. M., \& Facco, G. (2012). Tamanho de amostra para a estimação da média do comprimento, diâmetro e massa de sementes de feijão de porco e mucuna cinza. Ciência Rural, 42(9), 1541-1544. https://doi.org/10.1590/S0103-84782012005000057 
Dourado, M. C., Silva, T. R. B., \& Bolonhezi, A. C. (2001). Matéria seca e produção de grãos de Crotalaria juncea L. submetida à poda e adubação fosfatada. Scientia Agrícola, 58(2), 287-293. https://doi.org/ 10.1590/S0103-90162001000200011

Empresa Brasileira de Pesquisa Agropecuária. (1999). Centro Nacional de Pesquisa de Solos (Rio de Janeiro, RJ). Sistema brasileiro de classificação dos solos. Brasília: Embrapa-SPI.

Facco, G., Cargnelutti Filho, A., Lúcio, A. D., Santos, G. O., Stefanello, R. B., Alves, B. M., ... Kleinpaul, J. A. (2015). Sample size for morphological traits of pigeonpea. Semina: Ciências Agrárias, 36(6), 4151-4164. https://doi.org/10.1590/0103-8478cr20150852

Kappes, C., Arf, M. V., Arf, O., Gitti, D. C., \& Ferreira, J. P. (2012). Resposta da crotalária a épocas e subdoses de aplicação de glifosato. Bioscience Journal, 28(3), 373-383.

Lopes, H. M., Queiroz, O. A., \& Moreira, L. B. (2005). Características agronômicas e qualidade de sementes de crotalária (Crotalaria juncea L.) na maturação. Revista Universidade Rural: Série Ciências da Vida, 25(2), 24-30.

Masson, G. de L., Santana, D. R. S., Barbosa, R. H., Colman, B. A., \& Scalon, S. P. Q. (2015). Restrição hídrica no crescimento de plantas jovens de Crotalaria juncea L. (Fabaceae) em casa de vegetação. Enciclopédia Biosfera - Centro Científico Conhecer, 11(21), 1693-1701.

Nduhiu, N., Onyango, A., Makokha, A., \& Mugai, N. (2015). Effect of phosphorus on the agronomic performance of two crotalaria species in Kenya. Internacional Journal of Agronomy and Agricultural Research, 7(2), 199-204.

Salviano, A. C., Souza, G. S., Araújo, F. S., Souza, Z. M., \& Vieira, S. R. (2013). Spatial variability of nutrients in Crotalaria juncea grown in an eroded soil. Revista de Ciências Agrárias, 36(3), 331-339.

Santos, V. S., \& Júnior, J. H. C. (2003). Influência dos elementos meteorológicos na produção de adubos verdes, em diferentes épocas de semeadura. Revista Brasileira de Engenharia Agrícola e Ambiental, 7(1), 91-98. https://doi.org/10.1590/S1415-43662003000100015

Silva, M. P., Arf, O., Sá, M. E., Abrantes, F. L., Berti, C. L. B., Souza, L. C. D., \& Arruda, N. (2014). Palhada, teores de nutrientes e cobertura do solo por plantas de cobertura semeadas no verão para semeadura direta de feijão. Revista Agrarian, 7(24), 233-243.

Silva, P. S. L., Barbosa, Z., Goncalves, R. J. S., Silva, P. I. B., \& Nunes, G. H. S. (2005). Sample size for the estimation of some sorghum traits. Revista Brasileira de Milho e Sorgo, 4(2), 149-160. https://doi.org/ 10.18512/1980-6477/rbms.v4n2p149-160

Silva, P. S. L., Santos, L. E. B., Oliveira, V. R., Sousa, R. P., \& Fernandes, P. L. O. (2015). Sample size and sampling method for evaluation of characteristics of the sunflower. Revista Ciência Agronômica, 46(1), 144-154. https://doi.org/10.1590/S1806-66902015000100017

Storck, L., Garcia, D. C., Lopes, S. J., \& Estefanel, V. (2011). Experimentação vegetal. Santa Maria: UFSM.

Storck, L., Lopes, S. J., Cargnelutti Filho, A., Martini, L. F. D., \& Carvalho, M. P. (2007). Sample size for single, double and three-way hybrid corn ear traits. Scientia Agricola, 64(1), 30-35. https://doi.org/10.1590/ S0103-90162007000100005

Teodoro, P. E., Junior, C. A. S., Ribeiro, L. P., Silva, F. A., Corrêa, C. C. G., Zanuncio, A. S., \& Torres, F. E. (2015). Sample dimension for estimation of biomass and yield of Sunn (Crotalaria juncea L.) and Showy Rattlebox (C. spectabilis Roth.). Journal of Agronomy, 14(2), 98-101. https://doi.org/10.3923/ja.2015. 98.101

Teodoro, P. E., Ribeiro, L. P., Silva, F. A., Corrêa, C. C. G., Luz Junior, R. A. A., \& Torres, F. E. (2014). Sample size to estimate biomass and productivity of Canavalia ensiformis and Dolichos lablab. Revista de Ciências Agrárias, 37(3), 348-353.

Timossi, P. C., Teixeira, I. R., \& Cava, M. G. B. (2014). Produção de sementes de Crotalaria juncea em diferentes épocas de semeadura no Sudeste Goiano. Global Science and Technology, Rio Verde, 7(3), 58-66. https://doi.org/10.14688/1984-3801/gst.v7n3p58-66

Toebe, M., Both, V., Cargnelutti Filho, A., Brackmann, A., \& Storck, L. (2011). Dimensionamento amostral para avaliar firmeza de polpa e cor da epiderme em pêssego e maçã. Revista Ciência Agronômica, 42, 1026-1035. https://doi.org/10.1590/S1806-66902011000400027 
Wang, K. H., Mcsorley, R., Marshall, A. J., \& Gallaher, R. N. (2004). Nematode community changes associated with decomposition of Crotalaria juncea amendment in litterbags. Applied Soil Ecology, 27(1), 31-45. https://doi.org/10.1016/j.apsoil.2004.03.006

\section{Copyrights}

Copyright for this article is retained by the author(s), with first publication rights granted to the journal.

This is an open-access article distributed under the terms and conditions of the Creative Commons Attribution license (http://creativecommons.org/licenses/by/4.0/). 